\title{
SPECIFICS OF MANAGEMENT OF ENTERPRISE INNOVATION ACTIVITIES IN THE CZECH REPUBLIC - THE DECISION-MAKING MECHANISM
}

\author{
Jindra PETERKOVÁ, Jiří FRANEK \\ VŠB - Technical University of Ostrava
}

\begin{abstract}
:
The majority of Czech managers are aware that the long-term competitiveness of the company depends primarily on the use of innovative technical solutions and investments in new technologies. Despite awareness of the importance of innovation, many companies do not know how to manage, implement, and evaluate them. Empirical research showed that most innovation firms implement, but do not systematically manage the implementation of innovative projects and the allocation of funds. There is a contradiction between companies' ability to orientate themselves in the approaches available in the area of innovation management and the existence of a large number of approaches that can be used to address a particular type of innovation problem. A set of innovation concepts has been created to solve those challenges. Practical steps of the decision-making mechanism for selecting innovation concepts have been proposed. The decision-making mechanism is based on the analytic hierarchy process (AHP) and serves primarily for managers of medium and large enterprises.
\end{abstract}

Key words: AHP method, innovation activities, innovation concept, innovation management

\section{INTRODUCTION}

The results of the statistical survey of innovation for the period $2012-2014$ show that $42 \%$ of enterprises realize innovation activities [16]. However, from an international perspective, enterprises in the Czech Republic innovate less than the EU27 average (49\% for 2010-2012) [16]. Innovations are most intensively implemented by large enterprises and, regardless of the size of the enterprise, more technical innovations than non-technical innovations. In terms of enterprise ownership, large and small enterprises with foreign control (54\%) innovate more than domestic enterprises (39\%) [16]. What is the success of innovative businesses? Successful innovative companies know why to innovate and not only reduce costs, what types of innovation can be realized, and what benefits from implemented innovations arise. At the same time, they are able to manage innovation activities and evaluate the effects of them $[21,24]$. On the one hand, many companies are aware of the importance of innovation for their further development, but they do not know how to manage, implement and evaluate innovations $[11,28,30]$. It leads to the following questions for managers: Can innovation be managed at all? In the case innovations can be managed, how to you approach to it? It is pointed out that innovation can be managed, but it is not easy $[15,23]$. Innovations are a key business process that is linked to the change of what an enterprise offers how it is created and delivered to the customer. On the other hand, literature and business re- sources provide a great number of principles on how to create an innovative business, the best practices of successful companies, and a range of approaches to innovation management, innovation implementation and evaluation. There is a contradiction between companies' ability to orient themselves in the approaches available in the area of innovation management and the existence of a large number of approaches that can be used to address a particular type of innovation problem. Suggestions for solutions that respond to the enterprise's ability to innovate are called concepts in the paper.

The primary goal of the paper is to present results of performed empirical research on the management of innovation activities of enterprises in the Czech Republic on a selected sample of enterprises, and to create a set of innovation concepts that can be used to solve innovative problems. Secondary goal is to create a set of decision-making criteria with the help of expert team for practical use based on the AHP method. This decision-making mechanism will make it easier for business managers to decide on the choice of concepts of innovation.

\section{RESEARCH METHODOLOGY}

Empirical research

The empirical research lasted 2 months. During this time personal interviews in companies on the basis of pre-prepared questions were done. Data obtained from empirical research on a selected sample of 130 companies was pro- 
cessed by SPSS. Determination of the type of implemented innovation management model in selected companies is based on a theoretical model of innovation management which is modified for the purpose of the research [30]. A selective analysis is performed to assess differences in types of innovation management models with respect to enterprise size. The Pearson's chi-squared test was used for the assessment.

\section{Innovations concepts}

Selection of the concepts presented in this paper reflects the level of reached research findings in the time of the paper submitting. Set of 10 innovation concepts was worked out based on searches, see Table 1.

Table 1 Set of 10 Innovation Concepts

\begin{tabular}{|c|c|c|}
\hline Concept title & $\begin{array}{c}\text { Concept } \\
\text { Abbreviation }\end{array}$ & $\begin{array}{l}\text { Determination } \\
\text { according } \\
\text { to following } \\
\text { authors }\end{array}$ \\
\hline $\begin{array}{l}\text { Concept based on measure- } \\
\text { ment of innovation perfor- } \\
\text { mance }\end{array}$ & $\mathrm{I}_{1}$ & $\begin{array}{r}{[27],[6],[32],} \\
{[19]}\end{array}$ \\
\hline Concept Balanced Scorecard & $\mathrm{I}_{2}$ & [9], [20] \\
\hline $\begin{array}{l}\text { Concept based on the evalua- } \\
\text { tion of innovations through in- } \\
\text { vestment efficiency indicators }\end{array}$ & $\mathrm{I}_{3}$ & {$[1],[25],[7]$} \\
\hline Concept of value analysis & $\mathrm{I}_{4}$ & [17], [29] \\
\hline $\begin{array}{l}\text { Concept based on organiza- } \\
\text { tional readiness for innovation }\end{array}$ & $I_{5}$ & [6] \\
\hline $\begin{array}{l}\text { Concept based on determina- } \\
\text { tion of innovative potential }\end{array}$ & $\mathrm{I}_{6}$ & [14], [18], [10] \\
\hline $\begin{array}{l}\text { Concept based on the creation } \\
\text { of innovative radar }\end{array}$ & $\mathrm{I}_{7}$ & [27], [6] \\
\hline $\begin{array}{l}\text { Concept based on the innova- } \\
\text { tion index }\end{array}$ & $\mathrm{I}_{8}$ & [6] \\
\hline $\begin{array}{l}\text { Concept based on an innova- } \\
\text { tive interactive panel }\end{array}$ & $l_{9}$ & {$[3],[5]$} \\
\hline $\begin{array}{l}\text { Concept based on experience } \\
\text { from corporate practice }\end{array}$ & $\mathrm{I}_{10}$ & [12], [13] \\
\hline
\end{tabular}

Source: [22].

\section{Criteria creation for innovation concept selection}

On the basis of an experts' discussion ( $3+3$ persons) a list of 8 criteria was elaborated in order to evaluate innovation concepts. Criteria were mainly assessed according to their use (operability), the tightness of the links among the individual criteria (independence) and whether they are not overdeveloped (non-redundancy). In case of 5 criteria (from 8) selected by the expert group it is possible to determine order of importance. Selected criteria $C_{1}$ to $C_{5}$, see Table 2, have the nature of the maximization criteria, that is, the best variants according to this criterion have the highest values. Criteria $C_{1}, C_{2}, C_{3}, C_{4}, C_{5}$ evaluate an object by expressing a certain intensity of the rating on a given scale from 1 to 5 .
Table 2 Chosen criteria for applications in decision models
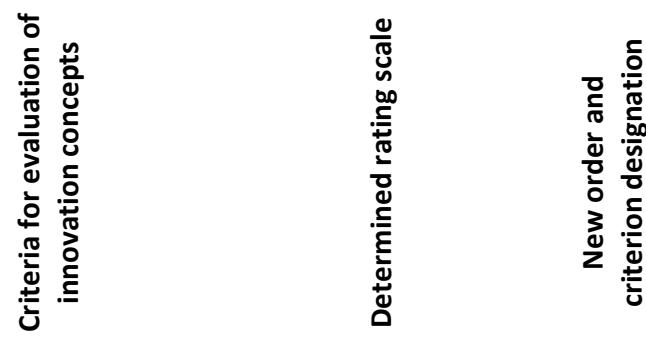

\begin{tabular}{|c|c|c|}
\hline $\begin{array}{l}\mathrm{C}_{3} \text { - applicability of the } \\
\text { concept of innovation } \\
\text { in practice }\end{array}$ & $\begin{array}{l}\text { (1 - very low, } \\
2 \text { - low, } 3 \text { - average, } \\
4 \text { - high, } 5 \text { - very } \\
\text { high). }\end{array}$ & $\mathrm{C}_{1}$ \\
\hline $\begin{array}{l}C_{5} \text { - usability of the con- } \\
\text { cept of innovation in an } \\
\text { enterprise }\end{array}$ & $\begin{array}{l}\text { (1 - very low, } \\
2 \text { - low, } 3 \text { - average, } \\
4 \text { - high, } 5 \text { - very } \\
\text { high). }\end{array}$ & $\mathrm{C}_{2}$ \\
\hline $\begin{array}{l}\mathrm{C}_{6} \text { - level of elaboration } \\
\text { of the concept of inno- } \\
\text { vation into manage- } \\
\text { ment levels }\end{array}$ & $\begin{array}{l}\text { (1 - very low, } \\
2 \text { - low, } 3 \text { - average, } \\
4 \text { - high, } 5 \text { - very } \\
\text { high). }\end{array}$ & $C_{3}$ \\
\hline $\begin{array}{l}\mathrm{C}_{7} \text { - determination of } \\
\text { innovation metrics and } \\
\text { their form }\end{array}$ & $\begin{array}{l}\text { (1 - very low, } \\
2 \text { - low, } 3 \text { - average, } \\
4 \text { - high, } 5 \text { - very } \\
\text { high). }\end{array}$ & $\mathrm{C}_{4}$ \\
\hline $\begin{array}{l}\mathrm{C}_{8} \text { - savings resulting } \\
\text { from training of existing } \\
\text { employees when imple- } \\
\text { menting the concept of } \\
\text { innovation }\end{array}$ & $\begin{array}{l}\text { (1 - very low, } \\
2 \text { - low, } 3 \text { - average, } \\
4 \text { - high, } 5 \text { - very } \\
\text { high). }\end{array}$ & $C_{5}$ \\
\hline
\end{tabular}

Procedural steps of the AHP method

The AHP method is based on pair-wise comparisons to determine priorities. The partial goal of AHP is to reduce the number of scale dimensions to one. The process of the analytic hierarchical process is determined by the following steps $[4,22,31]$ :

- Determining the weights of the criteria using the Saaty method (quantitative pair-wise comparison) and determining the order of the individual criteria based on the calculated weights $w_{i}$ according to the formula (1), checking the consistency of the matrix pair comparison (2).

- Assessing each variant based on the Saaty scale preferences (1-9) in each criterion and calculating the weights by means of the geometric mean of the lines (2) and then verifying the consistency of the pair-wise comparison matrix (3).

- Creating an AHP matrix, the weights of the criteria and weights of each variant in the relevant criteria.

- Calculation the final score (the weighted sum of each criterion weights and the weights of the respective variants) and determining the order of the variants.

- For determination of weights, we can use Saaty's method of quantitative pair-wise comparison based on the matrix $=s_{i j}$, where $i, j=1,2, \ldots, k$. The $s_{i j}$ elements of the pair-wise matrix represent estimated relative weights of the $i$-th and $j$-th criterion [8]: 


$$
s_{i j} \approx \frac{w_{i}}{w_{j}}
$$

where:

$i, j=1,2, \ldots, k$

Pair-wise comparison of the criteria determines the dimension of the preference, which is expressed by a certain number of points from the Saaty's scale: "1", $i$ and $j$ are equal, " 3 ", $i$ is slightly preferred to $j$, "5", $i$ is strongly preferred to $i$ and strongly preferred before $j, " 7 ", i$ is very strongly preferred to j, "9", $i$ is absolutely preferred to is given to j, values $2,4,6$ and 8 are left to evaluate the intermediate stages.

The decision-making is performed by using pair-wise comparisons of a set of items (criteria) $f_{1}, f_{2}, \ldots, f_{k}$ [8]. By comparing these items with each other the matrix $S=\left(s_{i j}\right)$ is created, where $i, j=1,2, \ldots, k$. It is now necessary to derive the weight of these items (criteria) from the pair-wise comparison matrix. The vector of their values is denoted by $v=\left(w_{1}, w_{2}, \ldots, w_{k}\right)$. Pair-wise comparison matrix $S$ contains quantified information about the relationship of the individual pairs of items illustrated in Figure 1 . The element $s_{i j}$ of this matrix can be interpreted as the ratio of the importance of the elements $f i$ and $f_{j}$. The elements on the diagonal have assigned value $s_{i i}=1$ (the criterion is equivalent to itself). The matrix $S$ is reciprocal, ie. must apply that $s_{i j}=1 / s_{i j}$ for all $i$.

$$
\begin{array}{ccccc} 
& f_{1} & f_{2} & \ldots & f_{k} \\
f_{1} & 1 & s_{12} & \ldots & s_{1 k} \\
f_{2} & 1 / s_{12} & 1 & & s_{2 k} \\
\vdots & \vdots & & & \\
f_{k} & 1 / s_{1 k} & 1 / s_{2 k} & \ldots & 1
\end{array}
$$

Fig. 1 General Outlook of the Saaty Matrix Source: [8].

In practice, the most commonly used method of weights determination is to use the row geometric mean method (RGMM) [8]. This solution is based on calculation of geometric mean of individual rows from the decision matrix (multiplying the elements of the individual rows of this matrix and determining the $k$ root of these sums). By normalizing these row geometric means (by dividing them by the sum of these geometric means) we obtain the criterion weights $w_{i}[8]$ :

$$
w_{i}=\frac{\left[\prod_{j=1}^{k} s_{i j}\right]^{\frac{1}{k}}}{\sum_{i=1}^{k}\left[\prod_{j=1}^{k} s_{i j}\right]^{\frac{1}{k}}}
$$

pro $i=1, \ldots, k$.

The consistency of pair-wise matrices is checked as a part of the process of determination of weight by Saaty method. Consistency should be checked before the weights determination with the aim to figure out whether the matrix is sufficiently consistent. The geometric consistency index $(\mathrm{GCl})$ was specifically created for the use of RGMM method of weights determination. The $\mathrm{GCl}$ is calculated as follows $[2,26]$ :

$$
G C I=\frac{2}{(n-1)(n-2)} \sum_{j \geq i}\left(\log \left(s_{i j}\right)-\log \frac{w_{i}}{w_{j}}\right)^{2}
$$

Where $n$ represents number of criteria, $w_{i} / w_{j}$ is Ratio of approximate weights. Approximate threshold values for consistency assessment were set by Escobar et al. (2004) as follows: $\mathrm{GCl}_{\max }$ for $\mathrm{n}=1.2$ is 0.31 ; for $\mathrm{n}=3$ then 0.3147 ; for $n=4$ is 0.3526 and for criteria number $n>4$ is 0.37 .

\section{FINDINGS}

\section{Results of empirical research}

The research sample consists of a random selection of 130 companies. Among the three largest groups of companies according to CZ-NACE belong: companies active in the wholesale and retail trade $21 \%$, followed by $18 \%$ of companies operating in manufacturing and $17 \%$ of companies in other activities. It was found that $92 \%$ of companies performed innovative activities from the research sample and the remaining $8 \%$ did not carry out any innovation. Research on a research sample did not confirm the results presented by the Czech Static Office that they are more innovating in large companies (32\%), as shown by the survey from the Czech Statistical Office. On the other hand, in the sample of surveyed companies surveyed small companies innovate more (37\%). In a larger scale, enterprises perform more technological innovations, i.e. product and process innovations (88\%), than non-technical, i.e. marketing and organizational innovations (57\%). Implementation of innovation is linked to innovation spending. These innovation-related expenditures are average for $51 \%$ of companies, high for $31 \%$ of surveyed firms and only for 5 companies (4\%) are very high.

It was found that $52 \%$ of businesses find incentives for innovations in customers, $34 \%$ of enterprises find incentives for innovations in competitors and $25 \%$ of companies draw innovations from own research. Companies use multiple sources to find incentives for innovation. It was found that the largest number of companies did not have any model to manage innovation activities (38.5\%). And, when the management model is applied, $31.5 \%$ of companies have a management model of an occasional character and $13.8 \%$ has enabling character. This means that there is no deliberate focus on innovation activity in the Occasional Management Model, and financial resources are not systematic but are only allocated after an assessment of the suitability of an innovative project. And in case of the Enabling Management Model, the implementation of innovative projects is scattered, only selected projects are supported and they are systematically supported financially. In only $16.1 \%$ of companies, innovations are targeted, either through the Producer Management Model (9.2\%) or through the Enforcing Management Model (6.9\%). In case of Producer Management Model, there exists support for the entire enterprise team and its systematic financial support. Also, for the Enforcing Management Model, there is support for the focused implementation of innovation activities, but only within the separate business units to which funds are allocated. The results are shown in Table 3. 
Table 3

Type of management model of innovations

\begin{tabular}{lcc}
\hline $\begin{array}{c}\text { Type of management model } \\
\text { of innovations }\end{array}$ & Frequency & $\begin{array}{c}\text { Valid } \\
\text { Percent }\end{array}$ \\
\hline No management model & 50 & 38.5 \\
Occasional management model & 41 & 31.5 \\
Enabling management model & 18 & 13.8 \\
Producer management model & 12 & 9.2 \\
Enforcing management model & 9 & 6.9 \\
Total & 130 & 100.0 \\
\hline
\end{tabular}

At the same time, a selective analysis was conducted to find out the difference between the choice of the innovation management model and the size of the enterprise. For enterprises up to 49 employees, the innovation management model is not used by $22 \%$, whereas for enterprises ranging from 50 employees it is $17 \%$. For enterprises of 50 employees, innovation is more systematically managed and financially supported. The difference in choice of the innovation management model with respect to enterprise size was statistically verified. A Pearson Chi-Square test was performed which had a value of 47.75 with 12 degrees of freedom, meaning that $55 \%$ had expected count less than 5 . The minimum expected count is 1.94 .

Selection of the innovation concept based on decision making mechanism

The application of the AHP method is used to organize 10 concepts of innovation based on a preference assessment of individual concepts within a given criterion. Before application of the AHP method author determined the weights of the individual criteria using the Saaty method and author also determined the order of each criterion based on the calculated weights $w_{i}$ according to the formula (1). The created Saaty matrix, see Table 4, is the result of the consensus of the expert group of $(3+3)$ who have agreed on the evaluation of the pair comparison in the table with the assistant of the investigator (author).

Table 4 Determination of the Weights of the Criteria Using the Saaty Matrix

\begin{tabular}{|c|c|c|c|c|c|c|c|c|}
\hline 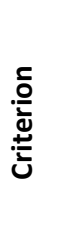 & ज & $\mathcal{N}$ & N & 寸 & ن & 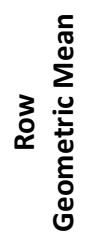 & 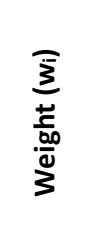 & 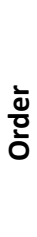 \\
\hline$C_{1}$ & 1 & 2 & 8 & 8 & 8 & 4.000 & 0.504 & 1 \\
\hline$C_{2}$ & $1 / 2$ & 1 & 6 & 6 & 6 & 2.551 & 0.321 & 2 \\
\hline$C_{3}$ & $1 / 8$ & $1 / 6$ & 1 & $1 / 2$ & 3 & 0.500 & 0.063 & 3 \\
\hline $\mathrm{C}_{4}$ & $1 / 8$ & $1 / 6$ & 2 & 1 & $1 / 2$ & 0.461 & 0.058 & 4 \\
\hline$C_{5}$ & $1 / 8$ & $1 / 6$ & $1 / 3$ & 2 & 1 & 0.425 & 0.054 & 5 \\
\hline
\end{tabular}

Check of the consistence of Saaty pair-wise comparison matrix was provided; see Table 4 with the help of consistency index $\mathrm{GCl}$. Geometrical consistency index $\mathrm{GCl}$ was calculated ( 3 ) and its value is 0.37 which refers to the limit value for the 5 criteria. The calculations made when applying AHP method are performed in MS Excel.
The decision-making mechanism based on AHP method was used to organize 10 concepts of innovation based on the preference assessment of individual concepts within a given criterion. Then each innovation concept variant was assessed on the basis of Saaty scale ( 1 to 9 ) in criterion $C_{1}$, $C_{2}, C_{3}, C_{4}, C_{5}$. The preferences of the concepts were calculated using the geometric mean of rows (2). The consistency of the pair-wise comparison matrices was checked using the $\mathrm{GCl}$ consistency geometric index (3). $\mathrm{GCl}(2,3)$ score was $0.369<0.37$, thus the pair-wise comparison matrix is consistent. AHP matrix was created using criteria weights and preferences or particular innovation concepts (variants) in the relevant criteria, see Table 5.

Table 5

Matrix AHP

\begin{tabular}{|c|c|c|c|c|c|c|}
\hline \multicolumn{2}{|c|}{ Criteria } & $C_{1}$ & $C_{2}$ & $\mathrm{C}_{3}$ & $\mathrm{C}_{4}$ & $\mathrm{C}_{5}$ \\
\hline \multicolumn{2}{|c|}{$\begin{array}{l}\text { Criteria } \\
\text { weights }\end{array}$} & 0.504 & 0.321 & 0.063 & 0.058 & 0.054 \\
\hline \multirow{10}{*}{$\begin{array}{l}\frac{n}{0} \\
\stackrel{0}{0} \\
\stackrel{0}{0} \\
0\end{array}$} & $\mathrm{I}_{1}$ & 0.025 & 0.053 & 0.121 & 0.148 & 0.213 \\
\hline & $\mathrm{I}_{2}$ & 0.217 & 0.180 & 0.121 & 0.148 & 0.078 \\
\hline & $I_{3}$ & 0.025 & 0.053 & 0.121 & 0.148 & 0.298 \\
\hline & $\mathrm{I}_{4}$ & 0.174 & 0.345 & 0.121 & 0.148 & 0.056 \\
\hline & $\mathrm{I}_{5}$ & 0.156 & 0.053 & 0.017 & 0.034 & 0.156 \\
\hline & $I_{6}$ & 0.156 & 0.180 & 0.121 & 0.034 & 0.056 \\
\hline & $\mathrm{I}_{7}$ & 0.025 & 0.016 & 0.121 & 0.034 & 0.018 \\
\hline & $\mathrm{I}_{8}$ & 0.025 & 0.053 & 0.121 & 0.148 & 0.053 \\
\hline & و & 0.025 & 0.016 & 0.017 & 0.011 & 0.017 \\
\hline & $\mathrm{I}_{10}$ & 0.174 & 0.053 & 0.121 & 0.148 & 0.055 \\
\hline
\end{tabular}

Finally, the resulting score (the weighted sum of criteria weights and the preferences of respective variants) has been calculated and the order of the variants is shown in Table 6.

Table 6

Final order of innovation concept

$\begin{array}{cllllllllll}\begin{array}{c}\text { Innovation } \\ \text { concepts }\end{array} & I_{1} & I_{2} & l_{3} & I_{4} & I_{5} & I_{6} & I_{7} & I_{8} & I_{9} & I_{10}\end{array}$

\begin{tabular}{|c|c|c|c|c|c|c|c|c|c|}
\hline $\begin{array}{l}\text { Resulting } \\
\text { score }\end{array}$ & 蒿 & 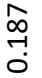 & $\begin{array}{l}\widetilde{0} \\
0\end{array}$ & 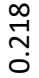 & ô. & 昌 & $\stackrel{\infty}{0}$ & $\stackrel{\infty}{0}$ & $\begin{array}{l}\text { Oे } \\
\text { ○ }\end{array}$ \\
\hline
\end{tabular}

Order

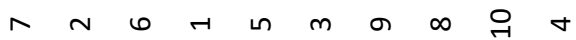

\section{CONCLUSION}

The empirical research was performed on a sample of 130 selected companies and it was found that the vast majority of companies are implementing innovative activities, with more innovating small firms than large. To a greater extent, companies are implementing technological innovations, which are realized with average expenses. Companies are looking for incentives to innovate, especially at the side of customers, competitors, and own research. At the same time, it was found that the largest number of companies did not have any model of innovative activity 
management. And when the management model is applied, the most often is Enabling Management Model and Occasional Management Model. On the basis of the selected analytical survey, the difference between the choice of innovation management model with respect to the micro, small, medium and large enterprise was determined.

A set of 10 innovation concepts $\left(I_{1}-I_{10}\right)$ was created. This file cannot be considered as the definitive list of existing innovation concepts. The created file responds to the researcher's research findings and to the availability of resources from which the paper was processed.

The concepts of innovation were chosen through a pairwise comparison method and analytical hierarchical process (AHP). Prior to the selection of concepts of innovation with respect to their applicability in the company, a list of five criteria for their evaluation was created. An expert team of three business experts and three academics was created to ensure objectivity in defining criteria and choosing concepts of innovation.

The result of the AHP implementation is the successive decision-making steps that can be applied in the decisionmaking mechanism for selecting innovation concepts. The decision-making mechanism is particularly suitable for managers of medium to large enterprises. It will enable managers to simplify the choice of a specific concept of innovation for business application. At the same time, the presented decision-making steps can be a guide for managers to create their own decision-making mechanism when changing criteria or a set of innovation concepts.

\section{ACKNOWLEDGEMENTS}

This paper was supported within Operational Programme Education for Competitiveness - Project No. CZ.1.07/2.3.00/20.0296. The paper is supported by the Czech Science Agency standard project (17-22662S).

\section{REFERENCES}

[1] J. Dvořák. Management inovací. Praha: Vysoká škola manažerské informatiky a ekonomiky, 2006.

[2] M.T. Escobar, J. Aguarón and J.M. Moreno-Jimenez. "A note on AHP group consistency for the row geometric mean priorization procedure". European Journal of Operational Research, vol. 153, pp. 318322, 2004.

[3] S. Few. Information Dashboard Design. Sebastopol: O’Reilly Media, 2006.

[4] J. Franek and A. Kresta. "Competitive Strategy Decision Making Based On The Five Forces Analysis With AHP/ANP Approach", in Economic Forum - 11th International Conference Liberec Proceedings, 2013, pp. 135-145.

[5] L. Gala, J. Pour and Z. Šedivá. Podniková informatika. Praha: Grada, 2009.

[6] P. Gupta and B.E. Trusko. Global Innovation Science Handbook. USA: McGraw-Hill Education, 2014.

[7] J. Hauschildt. Innovations management. Mnichov: Vahlen Franz GmbH, 2004.
[8] Ishizaka, and A. Labib. "Review of the main developments in the analytic hierarchy process". Expert Systems with Applications, vol. 38, pp. 14336-14345, 2011.

[9] R.S. Kaplan and D.P. Norton. Efektivní systém řízení strategie. Nový nástroj zvyšování výkonnosti a vytváření konkurenční výhody. Praha: Management Press, 2010.

[10] A. Kopčaj. Spirálový management. Praha: Alfa Publishing, 2007.

[11] V. Koráb and P. Koudelková. "What determines innovation in small and medium enterprise? A Case study from the Czech Republic". Transformations in Business \& Economics, vol. 15, pp. 78-88, 2016.

[12] J. Košturiak and J. Chal. Inovace vaše konkurenční výhoda! Brno: Computer Press, 2008.

[13] J. Košturiak and Z. Frolík. Štíhlý a inovativní podnik. Praha: Alfa Publishing, 2006.

[14] M. Kovač and D. Sabadka. "Model inovačního potenciálu podniku”. Transfér inovacií, vol. 7, pp. 3-6, 2004.

[15] L. Ludvík and J. Peterková. “Management approaches of large and small enterprises in Czech Republic". Actual Problems of Economics, vol. 155, pp. 36-45, 2014.

[16] M. Mana. "Inovační activity podniků v ČR 20122014". Internet: https://www.czso.cz/documents/10180/23195482/kp_213003_16.pdf/03553 022-afae-43ef-85ca-ca6afb197333?version=1.1, Jun. 3, 2016 [Dec. 29, 2017].

[17] L.D. Milles. Techniques of Value Analysis and Engineering. New York: McGraw-Hill, 1972.

[18] Z. Mikoláš, J. Peterková, M. Tvrdíková et al. Konkurenční potenciál průmyslového podniku. Praha: $\mathrm{C}$. $\mathrm{H}$. Beck, 2011.

[19] J. Mlčoch. Inovace a výnosnost podniku. Praha: Linde, 2002.

[20] D. Parmenter. Key Performance Indicators. New Jersey: John Wiley \& Sons Ltd, 2010.

[21] M. Pearl. Grow Globally. New Jersey: Wiley, 2011.

[22] J. Peterková. Využití konceptů inovací v průmyslovém podniku. Ostrava: VŠB-TU Ostrava, 2018.

[23] J. Peterková and L. Ludvík. Řízení inovací v průmyslovém podniku. Ostrava: VŠB-TUO, 2015.

[24] J. Peterková and Z. Wozniaková. "The Czech innovative enterprise". Journal of Applied Economics Sciences, vol. 10, pp. 243-252, 2015.

[25] Z. Pitra. Management inovačních aktivit. Praha: Professional Publishing, 2007.

[26] T.L. Saaty and K. Peniwati. Group Decision Making: Drawing out and Reconciling Differences. Pitsburgh: RWS Publications, 2012.

[27] M. Šulák and E. Vacík. Měření výkonnosti firem. Praha: EUPRESS, 2005.

[28] J. Tidd and J. Bessant. Managing Innovation: Integrating Technological, Market and Organizational Change. Chichester: John Wiley \& Sons Ltd, 2013.

[29] R. Vlček. Strategie hodnotových inovací: tvorba, rozvoj a měřitelnost inovací. Praha: Professional Publishing, 2011. 
[30] R.C. Wolcott and M.J. Lippitz. "The Four Models of Corporate Entrepreneurship". MITSloan Management Review, vol. 49, no. 1, pp. 75-82, 2007.

[31] Z. Zmeškal. "Application of decomposition multi-attribute methods AHP and ANP in financial decisionmaking", in Managing and Modelling Of Financial Risks - 6th International Scientific Conference Proceedings, 2012, pp. 689-699.

[32] O. Žižlavský. (2012). Hodnocení inovační výkonnosti. [On-line]. Available: www.inoinfra.cz/userfiles/file/ Hodnocení inovační výkonnosti.pdf [Oct. 28, 2017].

\section{Ing. Jindra Peterková PhD.}

Ing. Jiří Franek PhD.

VŠB-Technical University of Ostrava

Faculty of Economics

Sokolská třída 33, 70200 Ostrava, Czech Republic

e-mail: jindra.peterkova@vsb.cz

jiri.franek@vsb.cz 